\title{
Emotions in trauma team
}

\author{
Annette Jakobsen \\ From 4th Danish Emergency Medicine Conference \\ Roskilde, Denmark. 25-26 November 2011
}

\section{Background}

This study shows how emotions are expressed in a trauma team setting and assesses their influence and importance with regard to team performance.

The term "Team emotion" can be interpreted as the emotions that trauma team members do/do not display in a trauma receiving unit. Health care professionals are expected to refrain from showing emotion in the presence of patients and colleagues, but at the same time these emotions have a provable effect on teamwork.

\section{Methods}

The study uses a qualitative, theme-based analysis of data acquired in semi-structured interviews with trauma team nurses in which they were asked to describe and assess their own emotions - and how these were expressed - during trauma receiving situations. Participant observation studies of the trauma team were also completed, along with audits and analysis of the medical records.

The study took place at a large Danish University Hospital, housing a Level One Trauma Centre.

\section{Results}

The study confirmed the general belief that the showing of emotions, particularly if these are regarded as "negative" is not widely accepted within a trauma team. Displays of hope and/or happiness are acceptable, but emotions such as fear, anxiety, sadness and anger are considered inappropriate. Overt emotional response is considered more acceptable in certain professional groups than in others. From the interviews it was concluded that doctors were expected to be "above" emotional displays and the explicit norms within the organisation have a strong influence. In contrast, it is considered more acceptable for nurses to display

Correspondence: annjak@rm.dk

Faelles Akut Afdeling, Aarhus Universitetshospital, Denmark

Submit your next manuscript to BioMed Central and take full advantage of:

- Convenient online submission

- Thorough peer review

- No space constraints or color figure charges

- Immediate publication on acceptance

- Inclusion in PubMed, CAS, Scopus and Google Scholar

- Research which is freely available for redistribution

\section{( Biomed Central}

(c) 2012 Jakobsen; licensee BioMed Central Ltd. This is an Open Access article distributed under the terms of the Creative Commons Attribution License (http://creativecommons.org/licenses/by/2.0), which permits unrestricted use, distribution, and reproduction in any medium, provided the original work is properly cited. 